\title{
Review the Mind of Mohammad Hatta for the Contemporary of Indonesian Democracy
}

\author{
Farid Luthfi Assidiqi ${ }^{1}$ \\ \{faridluthfi000@gmail.com $\}^{1}$ \\ Universitas Diponegoro, Indonesia ${ }^{1}$
}

\begin{abstract}
Mohammad Hatta is one of the founders of the nation, as well as a thinker who controls various Western disciplines, but still adheres to Indonesian values. His thoughts on democracy include popular democracy and economic democracy with the principle of popular sovereignty. The results of this study are that all elements of the nation need to actualize the thinking of Mohammad Hatta trying to apply the concept of Democratic Democracy and Economic Democracy by re-learning his concept of thought and making policies that enable Mohammad Hatta's democratic concept to be implemented.
\end{abstract}

Keywords: People's Sovereignty, Popular Democracy, Economic Democracy.

\section{Introduction}

Mohammad Hatta or familiarly called Bung Hatta was one of the thinkers who became the founding father of the Indonesian nation. Bung Hatta, the first hero of the Indonesian Proclamator and Deputy President, has laid the foundations of nation and state through struggle and thought enshrined in the form of written works. Bung Hatta had been educated in the Netherlands but because Nationalism and his understanding of Indonesia made his work very feasible to study theoretically. Bung Hatta devoted his thoughts by writing various books and writing columns in various newspapers both at home and abroad. It has been known together that Bung Hatta's work was so diverse, his thinking about nationalism, Hatta implemented the idea of nationalism that had arisen since school through his politics of movement and leadership in the movement organization at the Indonesian Association and Indonesian National Education. While Hatta's thinking about democracy by emphasizing mutual cooperation was the concept of popular sovereignty which later gave birth to the concept of popular democracy and economic democracy.

One of his works that discusses democracy in Indonesia is a book entitled Our Democracy, besides that there are many other Bung Hatta writings on democracy such as Indonesia's Original Democracy and the Sovereignty of the People. The problem is, what happened to the implementation of Indonesia's democracy at this time is partly not in line with the concept of democracy according to Mohammad Hatta. Talking about democracy should also talk about its implementation. The implementation of democracy in Indonesia has always been highlighted by various parties. Indonesia has implemented a system of government that looks like glorifying the people, but in its implementation the problems of democracy seem endless. Democracy in Indonesia looks successful on a system basis but in terms of implementation it is still far from expectations. Therefore, it is necessary to reflect on Mohammad Hatta's democratic thinking for the development of contemporary Indonesian democracy. 
Based on this background, the author is interested in conducting a study of the actualization of Mohammad Hatta's thoughts on the future development of Indonesian democracy.

The problems that can be formulated in the above problems are:

a. How was Mohammad Hatta's thinking about Democracy?

b. What should be done to actualize the thinking of Democracy Mohammad Hatta for the future development of Indonesian Democracy?

The research method used is a qualitative approach by collecting data through literature studies, discourse analysis theory, and hermeneutics. According to Stubs and Cook (Badara, 2012), discourse analysis is as a study that examines or analyzes language that is used naturally, both in oral and written forms. Furthermore, Stubs explained discourse analysis emphasizes the study of language use in context. Whereas hermeneutics according to Abdul Hadi (2008) is as a method of interpretation not only looking at the text, but the thing that cannot be abandoned is also trying to explore the content of its literal meaning. More than that, he tried to explore meaning by considering the horizons surrounding the text, both the author's horizon, the reader's horizon, and the horizon itself. Taking into account the three horizons, it is expected that the effort of understanding and interpretation will be a reconstruction activity and reproduction of the meaning of the text, in addition to tracking how a text is raised by the author and what contents enter and want to be included in the text, an interpretation activity actually attempts to regenerate meaning situations and conditions when the text is read and understood. This is in other words, as a method of interpretation, namely text, context, and contextualization.

\section{Result and Discussion}

The development of democratic thought Mohammad Hatta could not be separated from his family background and culture in his residence. Hatta's democratic thinking emerged beginning with his sense of nationalism. During the school year, Hatta began to open his thoughts through his views on human values which eventually developed into an attitude of Anti Colonialism and a sense of Nationalism emerged. Initially it was still limited to nationalism as a Sumatran, then it developed into nationalism extensively covering the entire territory of the Dutch East Indies with the discourse of Jong Indie. This is in accordance with the opinion of Hans Kohn [1] which states that nationalism is formed through equality of language, race, religion, civilization, state territory, and citizenship. Whereas Margaret Moore [2] says that a nation is a moral community characterized by solidarity and mutual trust. Then the nation is not based on culture, because national identity should not be confused with a shared culture. This was marked by the realization of "Sumpah Pemuda" in 1928.

Hatta's conception of democracy in Indonesia is based on three things. Hatta there are three main sources of democracy rooted in Indonesia. First, Western socialism defends the principles of humanism, while these principles are also considered as well as goals. Second, Islamic teachings command the truth and justice of God in society. Third, the pattern of people who live based on collectivism as found in Indonesian villages. According to Hatta, this organic combination between the three socio-religious power sources gave Hatta the belief that democracy had long been rooted in Indonesia, including in the villages.

Hatta's main democratic thinking was the concept of popular democracy and economic democracy based on popular sovereignty by introducing the term "people's sovereignty". The term was explicitly published by the Daulat Rakyat magazine when Bung Hatta became chairman of Indonesian National Education in 1932. People's Sovereignty according to Bung Hatta saw political democracy as well as economic democracy in it. Where the People's 
Sovereignty in Indonesia comes from the characteristics and attitudes of the Indonesian people themselves. People's sovereignty means making the people as kings who must be protected and prioritized from others. This means that all policies made by the government must be in accordance with the aspirations of the people [3].

According to Hatta in the book Complete Works of Bung Hatta volume 1 (2011) [4], the values of people's sovereignty, including power in the hands of the people, already exist in the old Indonesian society. Long before the arrival of colonialism, Indonesians, especially those living in villages, were accustomed to carrying out democratic values in people's lives, a practice which was later called village democracy. Bung Hatta then elaborated on three main characteristics of village democracy, namely: First, there was a meeting, which according to Hatta had existed in community life in Indonesia since time immemorial. Second, there are protests, namely the right of the people to refute regulations made by the government that are not in accordance with the will of the people. The third is collectivism or mutual cooperation, where the Indonesian people basically do not recognize absolute private ownership. This is in accordance with the opinion of David Held [5] which states that democratic autonomy requires statements of human rights outside the right to choose to provide equal opportunities to participate and to find personal preferences and final supervision by citizens on the political agenda.

The concept of popular democracy is then applied to the concept of democracy in the economic field. Bung Hatta's thinking about economic democracy was influenced by his criticism of imperialism and colonialism that occurred in Indonesia. According to Hatta [6] the capitalistic economic system of the Dutch East Indies only benefited the owners of capital, most of whom consisted of Dutch people and descendants like the Chinese. Whereas the indigenous people only become servants and laborers in their own country. This is consistent with the opinion of Caparaso and Levine [7] that the inequality of wealth distribution in the Capitalism system makes some have wealth that can enable them to hire other people to work for them, while others have to sell their labor to get the means to meet their needs.

Through knowledge of economic theory and cooperatives, Bung Hatta sparked a concept of economic democracy based on popular economy. Bung Hatta encouraged mutual cooperation between economic actors. In economic democracy, Hatta called it economic politics. In an effort to improve people's welfare, the explanation of rational economic theory is no longer sufficient, which needs to be considered is the view of life, state ideology, and various social, political and cultural factors that develop in society. So, Hatta found the socialist economy as the most appropriate economic order developed in the Independent Indonesian Country [8].

The ideals of democracy in Indonesia are broader in contrast to Western Democracy. Indonesian democracy is not only political democracy, but also economic democracy. With the existence of economic democracy, it can be guaranteed that social justice becomes the fifth pillar of the Republic of Indonesia, "Social justice for all Indonesian people." Social justice requires prosperity that is evenly distributed to all people. Popularism is not only in political relations, but also in economic and social affairs. The people must be given the right to determine their destiny in the broadest sense. Hatta wrote [9] the sovereignty of the Indonesian people includes both namely political democracy and economic democracy. The first characteristic, which is to make decisions in consensus with deliberation, is the basis of political democracy. The second nature namely help, and mutual cooperation is a joint to uphold economic democracy.

According to Robert Wesson [10] that democracy is not only manifested in the political sphere, but also in the fields of economics and socio-culture. Whereas Hegel's opinion [7] states that in this system, absolute ownership and ownership by the authorities are not recognized. One 
person will recognize the individual nature of others so that the autonomy that someone has is a result of the social conditions of that person. People who can run this system are people who already have an ethical order. This interdependence of individuals with the community makes people have to respect and protect certain traits, namely the people must protect the rights of the people in them.

The implications of the concept of Popular Democracy, People's Sovereignty and Economic Democracy are contained in the 1945 Constitution of the Republic of Indonesia. Indonesia guarantees people's sovereignty in all aspects, namely political, socio-cultural and economic. Following is the concern of democracy in the 1945 Constitution of the Republic of Indonesia. Firstly, the attention of the 1945 Constitution of the Republic of Indonesia Chapter X on "Citizens" (Original Manuscript) that democracy pays attention to politics which is then implicated in the NRI Constitution Article 28 of the 1945 Constitution which reads: association and assembly, issue thoughts with oral and written and so forth stipulated by law. " [11]

Secondly, the attention of the 1945 Constitution of the Republic of Indonesia concerning democracy in the social and cultural fields is stated in Article 18B paragraph (2) which affirms that: "The state recognizes and respects indigenous law units along with their traditional rights as long as they are alive and in accordance with community development and the principle of the Unitary State of the Republic of Indonesia, which is regulated in law "and Article 32 (paragraphs 1 and 2) which reads: (1) The state advances Indonesian national culture in the middle of world civilization by guaranteeing people's freedom in maintaining and developing its cultural values; and (2) The state respects and maintains regional languages as a national cultural wealth.

Third, Article 33 of the 1945 Constitution of the Republic of Indonesia, which was formulated by Bung Hatta which read [12]:

1. The economy is structured as a joint effort based on the principle of family.

2. Production branches that are important to the state and control the livelihood of many people are controlled by the state.

3. Earth and water and the natural wealth contained therein are controlled by the state and used as much as possible for the prosperity of the people.

Economic democracy aims to realize the prosperity of society, not prosperity as limited as people or groups, as happened in the capitalist economic system. In addition, Article 33 strongly feels that cooperatives are the embodiment of the family principle that underlies the Indonesian economy. According to Sri Edi Swasono [13], the success of cooperatives should be built on two principles, namely solidarity and the principle of individuality. The principle of solidarity emphasizes the desire to achieve mutual prosperity. Individuality rests on self-esteem and the ability of individuals to advance cooperatives. With the holding of these two principles, the cooperative will bring life to the collective life fairy that still maintains individualism.

Thus, Bung Hatta identified economic democracy with the prosperity of society, not individual prosperity. With independence in economic terms for the people, justice and welfare for the people can be realized. Indonesia not only gives sovereignty in terms of politics but also in economic affairs. Therefore, Indonesian democracy for Bung Hatta is a social patterned democracy or social democracy.

Bung Hatta's thinking about Democracy is still very relevant for Indonesia but still difficult to implement at this time. The economic democracy that Bung Hatta aspires to about the Indonesian economy cannot be seen at this time. Related to the implementation of Economic Democracy through Article 33 of the 1945 Constitution, Ruslina [14] states that Article 33 of the 1945 Constitution in the formation of Indonesian economic law was not fully implemented, 
because state officials did not understand the position of Article 33 of the 1945 Constitution as a moral message and the message of culture in the Republic of Indonesia in the field of economic life, is the demand for the constitution. This article not only provides guidance on the composition of the economy and the authority of the state to regulate economic activities, but reflects ideals, a belief that is held firmly and fought consistently by State leaders. The constitutional message is clear, that what is intended is a special economic system that is not capitalistic economy based on individualism, but an economic system based on togetherness and family based.

Amendments to the 1945 Constitution with the addition of two verses in article 33 should be able to sharpen the concept of Economic Democracy along with economic policies made, either through Laws or Government Regulations. In fact, until now the concept of Economic Democracy, which Bung Hatta had once initiated, could not be implemented. Practically the same as the Indonesian nation for many centuries under foreign occupation. The current economic system that is developing is still liberalistic, capitalistic, and free market.

Therefore, in order to be able to carry out the concept of Popular Democracy initiated by Bung Hatta, all parties need to re-understand the thought of the founding fathers of the nation who are very wise articulating the "shared sense" of the people into the 1945 Constitution, so that it derives its noble meaning from democracy. The essence of economic democracy is economic participation and economic emancipation. This is especially aimed at people's representatives in Parliament who have legislative duties. This must also be followed by the development of Indonesian economic law, understanding of togetherness and the principle of kinship as adhered to in Article 33 of the 1945 Constitution which is compelling, must be implemented consistently.

\section{Conclusion}

1. Mohammad Hatta's democratic thinking was motivated by a sense of nationalism and nationalism, initially limited to nationalism as a Sumatran, then nationalism in the Jong Indie discourse, until the emergence of thoughts about the establishment of a sovereign state with democracy in it.

2. Mohammad Hatta's concept of thinking about Indonesian Democracy is based on the People's Sovereignty, the concept of which is divided into Democratic Democracy and Economic Democracy. Popular democracy means making the people as kings who must be protected and prioritized from others. This means that all policies made by the government must be in accordance with the aspirations of the people. Economic democracy is an advanced concept of popular democracy in the economic field. Aims to realize the prosperity of society, not prosperity as limited as people or groups, as happened in the capitalist economic system. Bung Hatta realized that one of them was by establishing a Cooperation.

3. Contemporary Indonesia needs to review Hatta's democratic thinking as a reflection material for strengthening democracy in Indonesia. As well as a mirror whether the ideals of the Democratic Democracy and Economic Democracy have been carried out properly in accordance with the national goals and ideals of the founding fathers of the nation.

\section{References}


[1] M. S. Kaelan, "Filsafat Pancasila Pandangan Hidup Bangsa Indonesia," Yogyakarta, Paradig. Yogyakarta, 2002.

[2] G. F. Gaus and C. Kukathas, Handbook Teori Politik. Bandung: Penerbit Nusa Media, 2012.

[3] M. Hatta, Untuk Negeriku Sebuah Otobiografi Jilid Dua, Berjuang dan Dibuang. Jakarta: Kompas Media Nusantara, 2011.

[4] M. Hatta, Untuk Negeriku Sebuah Otobiografi Jilid satu, Bukittinggi-Rotterdam Lewat Betawi. Jakarta: Kompas Media Nusantara, 2011.

[5] S. Georg, "Demokrasi Dan Demokratisasi.” Pustaka Pelajar Yogyakarta, 1993.

[6] M. Hatta, Untuk Negeriku Sebuah Otobiografi Jilid Tiga, Menuju Gerbang Kemerdekaan. Jakarta: Kompas Media Nusantara, 2011.

[7] A. C. James and P. L. David, "Teori-Teori Ekonomi Politik." England: Cambridge University Press, 1992.

[8] M. Hatta, "Karya Lengkap Bung Hatta: Buku 4 Keadilan dan Kemakmuran,” Jakarta, LP3ES, 2015.

[9] M. Hatta, Demokrasi kita, dan pikiran-pikiran tentang demokrasi dan kedaulatan rakyat. Sega Arsy, 2008.

[10] M. Djafar, "Krisis Politik \& Proposisi Demokratisasi," Jakarta Bumi Aksara, 2015.

[11] "Undang-Undang Dasar NRI 1945 Disertai Penjelasannya Secara lengkap Amandemen I 19-101999, Amandemen II 18-08-2000, Amandemen III 1011-2001, dan Amandemen IV 10-08-2002. Diperbanyak oleh Penerbit Palito Media."

[12] M. Hatta, Politik, kebangsaan, ekonomi, 1926-1977. Penerbit Buku Kompas, 2015.

[13] M. A. Zain, "Politik Hukum Koperasi Di Indonesia (Tinjauan Yuridis Historis Pengaturan Perkoperasian Di Indonesia)," J. Penelit. Hukum-Fakultas Huk. Univ. Gadjah Mada, vol. 2, no. 3, pp. 160-177, 2015.

[14] E. Ruslina, "Makna Pasal 33 Undang-Undang Dasar 1945 dalam Pembangunan Hukum Ekonomi Indonesia," J. Konstitusi, vol. 9, no. 1, 2012. 